\title{
CrimRxiv
}

\section{La police au Nunavik}

Mylène Jaccoud, Marie-Claude Barbeau-Leduc, Myriam Spielvogel

Published on: Mar 31, 2021

License: Creative Commons Attribution 4.0 International License (CC-BY 4.0). 
